DOI: https://doi.org/10.32839/2304-5809/2021-9-97-9

UDC $81.37=111=161.2$

Savchenko Oksana

Drohobych Ivan Franko State Pedagogical University

\title{
LANGUAGE OBJECTIVATION OF THE NOTIONAL COMPONENT OF THE CONCEPTS ПOЛЕ/FIELD IN THE PROVERBIAL PICTURE OF THE WORLD
}

Summary. The article highlights the specifics of verbalization of the concepts ПОЛЕ/FIELD in the Ukrainian and English paroemia items. It also looks into the structure of these concepts, namely its notional component, as well as specifies isomorphic and allomorphic cognitive features of the concepts under contrastive study. It has been revealed that the concept ПОЛЕ gets broader objectivation in Ukrainian proverbial corpora in comparison with the concept FIELD, verbalized in the English paroemias which is predetermined by the geographical factor. The larger part of Ukraine comprises steppes and fields with rich soil which had an impact on the formation of the national character and outlook, the way of life and habits.

Keywords: concept, paroemia, proverbial corpus, language objectivation, notional component, cognitive features, world picture.

Савченко 0.0.

Дрогобицький державний педагогічний університет імені Івана Франка

\section{МОВНА ОБ’ЄКТИВАЦІЯ ПОНЯТЙНОГО СКЛАДНИКА КОНЦЕПТІВ ПОЛЕ/FIELD В ПАРЕМІЙНІЙ КАРТИНІ СВІТУ УКРАЇНЦІВ ТА АНГЛІЙЦІВ}

\begin{abstract}
Анотація. У статті здійснено аналіз особливостей мовної об'єктивації концептів ПОЛЕ/FIELD в українських та англійських паремійних одиницях. Окрім цього, досліджено структуру цих концептів, а саме понятійний складник, а також встановлено їхні спільні та етноспецифічні культурно зумовлені когнітивні ознаки. Термін паремія визначаємо як народні висловлювання, здебільшого повчального змісту, змістовно цілісні і синтаксично завершені, відтворювані речення, які лаконічно, в прямому або переносному значенні передають певні настанови чи істини. Вони є надійним засобом простеження національного менталітету, характеру та світогляду, культури, способу життя тощо. Концепт як багатовимірне ментальне утворення характеризується такими складниками: 1) понятійним; 2) перцептивно-образним; 3) ціннісним. Понятійний складник охоплюе логічні (прямі) семантичні ознаки. В ході дослідження з'ясовано, що паремії, в яких вербалізовано концепт ПОЛЕ є більш частотними в українській мові, аніж FIELD - в англійській. Широка об’ективація концепту ПОЛЕ в українському паремійному корпусі є закономірною, так як ландшафт України в більшій мірі рівнинний, а українські землі вирізняються родючістю. Ще одним чинником частотної репрезентації цього концепту є любов до фрізичної роботи в полі, яка є невід'ємною частиною українського менталітету. Український паремійний матеріал фріксує чимало народних висловлювань, які пов'язані з особливостями ведення сільськогосподарських робіт і відображають логему 'лише добре удобрена та оброблена земля проносить добрий врожай', а також 'поле забезпечує існування, без нього неможливо прожити'. Найбільш частотною когнітивною ознакою концепту ПОЛЕ, вербалізованою в паремійних одиницях української мови е 'місце сільськогосподарської праці', а найменш частотною - 'ознака достатку'. В англійській етносвідомості широко актуалізовано семантичну ознаку концепту FIELD - 'місце, яке приносить врожай, де ростуть злаки, ягоди, трави', а тематична група паремійних одиниць, в яких цей концепт вербалізуеться як 'місце бою' та 'місце полювання' в кількісному і якісному відношеннях найменш поширена.
\end{abstract}

Ключові слова: концепт, паремія, паремійний фонд, мовна об’ективація, понятійний складник, когнітивні ознаки, картина світу.

Droblem statement. Modern linguistic studies focuses on the linguistic world image of native speakers of different languages, the connection between language and culture, language and mentality, as well as the reflection of culture and national worldview in the language. All these factors have aroused interest of researchers in the problems of paroemic semantics, the interaction of linguistic and extralinguistic factors in the structure of meanings of proverbs and sayings, their ability to represent the peculiarities of national worldview and cognitive structures of experience. Despite the wide range of research on paroemic issues, the analysis of ways of verbalization of collective ideas of native speakers of Ukrainian and English languages about the natural conditions of their living, in particular on the material of paroemias of these languages needs special attention.
Analysis of recent research and publications. The semantics of landscape space names on the material of phraseological units in comparative or monostudies has been researched by such linguists as O. Halynska, T. Kosmeda, K. Mizin, J. Suleymanova, T. Panekina, I. Putova, V. Uzhchenko, O. Cherkhava and others.

The aim of this article is to define the common and different culturally determined semantic components of English and Ukrainian paroemia units with the names "поле"/"field" and their equivalents in their structure.

Discussion. In V. Uzhchenko's opinion, a field is one of the oldest and most constant landmarks in the nature and life of an ethnos. For a Ukrainian steppe dweller, this is not only a spatial phenomenon, but if only sufficiently representative material is involved, the course of an eventful life. The semantic part of this concept reflects the features 
that are perceived by the community as socially significant, mentally marked [6, p. 102].

In paroemia items the most common is a generally used lexemе "поле" and its equivalent in English "field". However, other verbalizers of the FIELD concept in the Ukrainian language are "луг", "пасовисько", “степ", and in English "meadow" and "pasture".

The study of common and distinctive features of verbalization of ПОЛЕ/ FIELD concepts in the English and Ukrainian paroemias shows that the common denotative feature of these concepts, verbalized in paroemia items of contrasted languages, which complements their notional component, is 'field as a place for movement with no obstacles to it'. A field in this meaning acts as a 'large, flat, open space'. It, unlike other relief elements, is convenient for movement: Вік прожити - не поле перейти [7, р. 365], Голодний поле перебіжить, а голий ні з місия [3, p. 303], Runs over fields and woods all day. Under the bed at night sits not alone, with long tongue hanging out, a-waiting for a bone (A shoe) [10, p. 152].

In Ukrainian riddles the subjects of movement in this locus are natural phenomena (wind, celestial bodies), wild animals, birds, body parts (eye), and in English - domestic animals (cow, horse), insects (bee), which are mostly the object of guessing: Летить коник, басує, полел-долел пустує, ніхто його не впійлия $i$ ніхто не загнуздає (Вітер) [8, р. 43], Маленьке, сіреньке, по полях літає, уночі співає (Перепілка) [8, р. 112], Way out in the field there stands a great mare, hoist up her tail and sop your bread there (Beehive with honey in it) [10, p. 138].

A steppe and a field in the Ukrainian proverbial picture of the world are distinguished by their beauty. These landscape objects arouse admiration, aesthetic pleasure from contemplation: Cmen, поля-розкіш лоя [3, p. 48].

The proverbial corpus of the Ukrainian language objectifies collective ideas about a field as a source of income, a sign of well-being and wealth: Як твоя, доню, доля, то накупить чоловік $i$ поля, а як безділля, то продасть $i$ подвір'я [5, p. 177]. However, there is an opposite popular statement about the advantages of a field for a household: Лinше мати гарну жінку, ніж сто ббалеч поля [4, p. 95]. In the Ukrainian s' collective ideas, the lack of a large plot of land for cultivation was the cause of ridicule, because it testified to the idleness of an owner: Поля, що й куриі лапкою нела, де ступити [3, р. 48], Тал того поля на заячий скік [3, p. 48].

In the common consciousness of Ukrainians it is 'a place of deception, insecurity, hardships, a hazardous and deserted land area': Вивів його в поле [1, p. 754], Пішло поле в ліс [1, р. 730]. In English lingoculture the specific national and cultural meaning of the lexeme 'field' is 'a place for walking a dog as well as 'a place for hunting': Dogs are fine in the field [11, p. 197], Game is cheaper in the market than in the fields [11, p. 160].

The national proverbial corpora of the languages under contrastive analysis records many paroemias in which the cognitive feature of the FIELD concept, in particular 'natural resource for human life' is verbalized. However, both in terms of qualitative and quantitative characteristics this feature receives a much broader reflection in the Ukrainian language: Без гною не раз поле вродит, а без ласки Божої ніколи [1, р. 500], Не збереш поля, коли лиха доля [5, p. 176], My father had a field, what was the first crop he made? (His track) [10, p. 426].

A field is a natural resource of two kinds: the former brings harvest on its own, being a place of berry picking: Не нашого поля ягода, лісцел, де ростуть трави: В лінивого на полі кропива pocme [4, p. 447]; Love is a fair garden and marriage a field of nettles [12, p. 174]; a pasture: Поле голубе, овечки золоті, пастух рогатий (Небо, зорi $i$ sicsub), Looked all over the house and couldn't find it, all over the barn and couldn't find it, looked out in the field and found it (A cow-bell) [10, p. 661]; ant the latter yields harvest as a result of hard human work.

There are a large number of paroemia items in the Ukrainian language, in which the interconnection 'field - work' is verbalized: Kpaщe pобитu на вільніл полі, ніж гуляти у неволі [5, p. 179]. Different types of work are performed in the field, namely - plowing, sowing, reaping, threshing, mowing: Чоловік у поле орать, а жінка рукали maxamb [4, p. 102]. To carry them out, various tools are used (a sickle, a plow, a cutter, a plow, a scythe) and machinery (a haymaker, a combine-harvester, a tractor): Лінивий у полі без сохи, а дола 3 ложкою [4, p. 449], Маленьке, кругленьке, усе поле обійшло і назад прийшло (Серп) [8, р. 225], If the moon shows a silver shield, be not afraid to reap your field, but if she rises haloed round, soon we'll tread on deluged ground [12, p. 280].

Mother Earth is a pre-polytheistic image-totem of proto-Ukrainians who worshiped the fertile field, the whole earth. For Ukrainians, the land (field) has always been a means of subsistence, a breadwinner, moreover, it is 'the mother's womb, in which not only the physical but also the spiritual genotype of man is formed". Consequently, a great number of paroemias, mostly in the Ukrainian language, are connected with the field as a place that yields, feeds, which any human-being cannot live without: Хто полю годить, полу жито родить [3, p. 49], Лimo poдums, а не поле [3, p. 81], Cockle and corn grow in the same field [11, p. 131].

The elements of the ПОЛЕ/ FIELD conceptosphere are zoonyms, particularly domestic animals, which in the Ukrainian common consciousness facilitate farming, but might sometimes fail in their work: Не вір жінці вдома, а коняиі в роботі [4, p. 94].

Ukrainian paremiological material comprises many a lot of expressions that are related to the peculiarities of field work. They verbalize the following logems: 'only well-cultivated and fertilized land yields a rich harvest': Не поле родить, а нива [5, p. 48], Гній у поле - одвезеш, більше хліба привезеш [5, p. 92].

Yield is determined by natural processes, namely the onset of summer: Jimo poдumb, a не поле [5, p. 81]. The biggest concerns of a representative of the Ukrainian ethnic group were associated with weather conditions, which could ruin all his work and destroy the crops: Зійти то зійшло, та якби з ниви не пішло [5, p. 101]. Soil fertility depends on God's will. This idea is defined by the Christian worldview and practical experience of the Ukrainian people: Без гною не раз нал поле 
вродит, а без ласки Божої ніколи [1, р. 500]. Ukrainian and English paroemias state that successful gathering in the harvest correlates with destiny and luck: Не збереш поля, коли лиха доля [5, p. 176], Fortune is the mistress of the field [12, p. 166]. In general, working in the field requires a lot of strenuous work: Гроші на полі не ростуть [5, p. 109], У полі пашня - як лава [3, p. 48], Горе поле не зоре, а біда не заволочить [5, p. 155], Журбою поля не виореш [5, p. 192]. This labour is challenging and sometimes exhausting: Не хвались, як ідеш у поле, ахвались, як ідеш із поля [4, р. 396], Поле в полю, а біди дола [1, р. 755], Нивко-нивко! Верни миюю силку [7, p. 453]. In the last mentioned paroemia a field is personified. It shows in the image of a patroness capable of working wonders.

English paroemias express the idea that three factors are essential to provide a good harvest: favorable weather conditions, healthy seeds and a hard-working farmer: A field requires three things: fair weather, sound seed and a good husbandsman $[12$, p. 42$]$, and successful field harvesting is the result of a farmer's dedication: It is the farmer's care that makes the field bare [9, p. 199].

Harvesting was a sacred act for the representatives of the Ukrainian ethnic group. It was accompanied by numerous rites. But not only wheat and rye were sacred grain crops for Ukrainians, but also other cereals: Кукурудзу шануй $i$ в полі, $i$ в силосній ялі, і в коморі [3, р. 110].

Ethnoculturally marked are the proverbs with the component "нива", which characterize the reality of Ukrainian society in the $16^{\text {th }}-19^{\text {th }}$ centuries (period of domination of serfdom), the second half of the $19^{\text {th }}$ - early $20^{\text {th }}$ centuries (spread of mercenaries among Ukrainian peasants), and expose social inequality, hard and exhausting work of serfs and hirelings, their impoverishment and deprivation: Побила лиха година, ота чужа нива та позичений серп [5, p. 162], Чужа нива силу зв'ялила [5, p. 101]. Folk beliefs objectivize the eternal desire of the Ukrainian peasant to free labor on his piece of land: Щоб лиха не знати треба своӥл плугол та на своїй ниві орати [5, p. 162]. This proverb has become figurative and more modern. One's own field is a metaphorical image of one's own country, homeland, Ukraine', and thus this paroemia appeals to Ukrainians to work in their country, not abroad, to avoid the bitter fate of migrant workers, which is also proved by another popular folk expression - На чужолу полі не матилеш волі [3, p. 607]. Landlords used to take land from poor peasants, for whom land and its crops were the main means of existence. However, this situation took on a humorous color in the paroemia, which reveals the optimistic and humorous character of a Ukrainian peasant: Ми дулали вже наша нива пропала, а вона втекла да пана Галагана [5, p. 230]. The image of someone else's field in Ukrainian paroemias represents 'alien which always seems better than one's own': На чужій нивi все ліпшая пшениия [7, p. 432]. The conception of another's field is built on the basis of sensory-image perception, when what is more distant was perceived as more attractive, more alluring.

The word "луг" in some Ukrainian paroemias conveys the seme: 'beauty': Гарна дівчина як $у$ лузі калина [4, p. 197] as well as joy: Не вдавайся в тугу, чекай шастя з зеленого лугу [5, р. 197]. The natural signs of a guelder-rose in the meadow, which is beautiful and red, are transferred to the image of a beautiful girl, and the meadow, which is especially enchanting in spring, is able to dispel any sorrow. A field in Ukrainian collective ideas exists as a "place for courtship, often an annoying опе': Не ходи по полю, не топчи куколю, не лупай очила, не твоя дівчина [4, p. 63].

In both languages there are proverbs and sayings that are associated with observations of nature, its changes at different times of the year, in particular, with the seasonal changes in the appearance of relief elements. Besides, they served as folk signs. Based on them a folk calendar was formed, which primarily regulated the time and nature of fieldwork. So, originally it was an agricultural calendar, which absorbed the centuries-old economic experience of the people, the main characteristics of which were love of farming, respect and care for the land, glorification of hard work which ensured life: Грудень поле гудить, а зеллю студить [3, р. 88], Як листя жовтіє, ліс $i$ поле смутніє [3, p. 48], Весна кличе в поле [3, р. 79], Не лякайся туланів - виїжджай у поле рано [3, р. 48], Від вересня вогонь і в полі, $і$ в хаті [3, p.88], Учервніна полі густо, а в колорі пусто [3, р. 87], У липні на дворі пусто, зате на полі густо [3, p. 88]. Church holidays were often the time reference points that defined the nature of agricultural activities: Fpiŭ з хати всіх на поле вижене [3, р. 391], Святий Юрій по полю ходить, хліб-жито родить [7, р. 58], По Петрі на дворі пусто, а на полі zycmo [3, p. 391]. Physical and functional properties of the field, depending on the time of the year, are realized by the Ukrainian riddle: Зимою біле, весною чорне, літол зелене, осінню стрижене (Поле) [8, p. 22], which implies the meaning of 'a field as a place for agricultural work', as well as its natural and physical features.

The English paroemia with the lexical component "field" expresses a sign, namely changes in the phase of the moon cycle, which predicts the weather, and with it the appropriate time for different types of field work, namely the harvest: If the moon shows a silver shield, be not afraid to reap your field; but if she rises haloed round, soon we'll tread on deluged ground [11, p. 542]. Another prognostic paroemia conveys the observation that precipitation in spring, such as snowfall in March and downpours in May, contribute to crop growth: A peck of March dust and a shower in May, makes the corn green and the fields gay [11, p. 511].

The field, particularly 'clear", steppe and meadow, are marked by the struggle against enslavement, for statehood, independence of Ukraine. The steppe, like the clear field, is the archetype of national consciousness, because these concepts are associates with fundamentals of human life such as space and freedom. As O. Yefymenko outlines, in the mentality of the Ukrainian people, the concept of steppe is very important, because the steppe zone occupies the vastest territory, $40 \%$ of the country's area, and the factor of the geographical environment of the native speaker influences the conceptual picture of a native speaker's world, which is reflected in his language picture of the world [2, p. 3]. 
And it is the Cossacks who are most often depicted in paroemias. The field for them is nothing but liberty, unlimited existence, where they can act at their own discretion, but without betraying the main goal - to protect the homeland from invaders and oppressors: Коли козак в полі, то він на волі [5, c. 263]. Therefore, the field is a place for battle, courage, victory, primarily of Cossacks', which is reflected in the Ukrainian paroemias: Cmen як дим [7, с. 450], Один в полі не воїн [5, с. 269]. And only one English paroemia qualifies a field as a place of fierce battle: Hard - fought field, where no man escapes unkilled [11, c. 353].

Conclusions and suggestions. The concept ПОЛЕ is one of the key concepts for Ukrainians, which is proved by the qualitative and quantitative objectification of this concept in the proverbial corpus of the Ukrainian language, the presence of numerous variants. Its diverse objectification is natural, as the landscape of Ukraine is mostly flat, and Ukrainian lands have always been known for fertility, which determined the national identity, as well as influenced lifestyle of the Ukrainian people. In the English proverbial corpus, the most frequent are paroemias with the meaning 'a place place where berries, grains, herbs grow', and in Ukrainian the most widely represented are paroemias, which verbalize the seme "place for farming, which testifies to the value of the agricultural aspect of the semantic content of the concept FIELD and characterizes Ukrainians as a hard-working nation that cherishes its hopes for prosperity by working in the field.

Prospects for further research are to analyze the objectivation of terrestrial and aquatic space concepts in the Ukrainian and English-language fiction discourses.

\section{References:}

1. Franko Ivan (ed.) (2006) Halytsko-ruski narodni prypovidky v 3 tomakh. Lviv: Vydavnychyi tsentr LNU imeni Ivana Franka, t. 1, 300 p.

2. Yefymenko O. Ye. (2005) Kontsept «step» v ukrainskii movi : slovnykova, tekstova i psykholinhvistychna paradyhma: dys. ... kand. filol. nauk: 10.02.01 / Kharkivskyi natsionalnyi pedahohichnyi un-t im. H. Skovorody, 266 p.

3. Paziak M. M. (ed.) (1989) Pryslivia ta prykazky. Pryroda. Hospodarska diialnist liudyny. Kyiv: Nauk. dumka, 480 p.

4. Paziak M. M. (ed.) (1990) Pryslivia ta prykazky. Liudyna. Rodynne zhyttia. Rysy kharakteru. Kyiv: Nauk. dumka, 528 p.

5. Paziak M. M. (ed.) (1991) Pryslivia ta prykazky. Vzaiemyny mizh liudmy. Kyiv: Nauk. dumka, 440 p.

6. Uzhchenko V. D. (2007) Kontsept pole u frazeolohichno-paremiinomu poli y poza yoho mezhamy. Linhvistyka: zb. nauk. prats. Luhansk: Alma-mater, no. 11, pp. 91-104.

7. Nomys M. (ed.) (1993) Ukrainski prykazky, pryslivia i take inshe. Kyiv: Lybid, 768 p.

8. Shestopal M. (1963) Ukrainski narodni zahadky. Kyiv: Vydavnytstvo Akademii nauk Ukrainskoi RSR, 398 p.

9. Mieder W. A (1992) Dictionary of American Proverbs. New York: Oxford University press, 710 p.

10. Taylor A. (1951) English Riddles from Oral Tradition. Berkeley and Los Angeles: University of California Press, 675 p.

11. Wilson F. P. (ed.) (1992) The Oxford Dictionary of English Proverbs. 3nd ed. Oxford: Clarendon Press, 930 p.

12. Fergusson R., Law J. (ed.) (2000) The Penguin Dictionary of Proverbs. 2nd ed. Penguin Books, 365 p.

\section{Список літератури:}

1. Галицько-руські народні приповідки : В 3-х т. Зібрав, упор. і поясн. др. Іван Франко. Львів : Видавничий центр ЛНУ імені Івана Франка, 2006. Т. 1. 300 с.

2. Єрименко О. Є. Концепт «степ» в українській мові: словникова, текстова і психолінгвістична парадигма : дис. ... канд. фрілол. наук : 10.02.01 / Харківський національний педагогічний ун-т ім. Г. Сковороди. Харків, 2005. 266 c.

3. Прислів’я та приказки. Природа. Господарська діяльність людини / упоряд. М. М. Пазяк. Київ : Наук. думка, 1989. $480 \mathrm{c}$.

4. Прислів'я та приказки. Людина. Родинне життя. Риси характеру / упоряд. М. М. Пазяк. Київ : Наук. думка, $1990.528 \mathrm{c}$

5. Прислів'я та приказки. Взаємини між людьми / упоряд. М. М. Пазяк. Київ : Наук. думка, 1991. 440 с.

6. Ужченко В. Д. Концепт поле у фразеологічно-паремійному полі й поза його межами. Лінгвістика : зб. наук. праць. Луганськ : Альма-матер, 2007. № 11. С. 91-104.

7. Українські приказки, прислів'я і таке інше / впорядкував М. Номис. Київ : Либідь, 1993. 768 с.

8. Шестопал М. Українські народні загадки. Київ : Видавництво Академії наук Української РСР, 1963.398 с.

9. Mieder W. A Dictionary of American Proverbs. New York : Oxford University press, 1992. 710 p.

10. Taylor A. English Riddles from Oral Tradition. Berkeley and Los Angeles : University of California Press, 1951.675 p.

11. The Oxford Dictionary of English Proverbs. 3nd ed. / ed. by F. P. Wilson. Oxford : Clarendon Press, 1992.930 p.

12. The Penguin Dictionary of Proverbs. 2nd ed. / ed. by R. Fergusson \& J. Law. Penguin Books, 2000. 365 p. 